Review Paper:

\title{
The Effects of Psychodrama on the Health of Adolescent Girls: A Systematic Review
}

\author{
Faezeh Daemi ${ }^{1} \mathbb{C}$, Seyedeh Fatemeh Vasegh Rahimparvar ${ }^{2,3 *}$ \\ 1. Department of Research in Art History, School of Art and Architecture, Tarbiat Modares University, Tehran, Iran \\ 2. Department of Midwifery and Reproductive Health, School of Nursing and Midwifery, Tehran University of Medical Sciences, Tehran, Iran
}

3. Nursing Care Research Center, Iran University of Medical Sciences, Tehran, Iran.

\begin{tabular}{|c|c|}
\hline $\begin{array}{l}\text { Use your device to scan } \\
\text { and read the article online }\end{array}$ & ditation Daemi, F. \& Vasegh Rahimparvar, S. F., 2018. The Effects of Psychodrama on the Health of Adolescent Girls: A \\
\hline 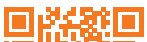 & Systematic Review. Journal of Client-Centered Nursing Care, 4(1), pp. 13-20. https://doi.org/10.32598/jccnc.4.1.13 \\
\hline 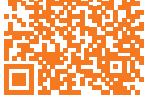 & d \\
\hline
\end{tabular}

Funding: See Page 19

(c) Copyright: The Author(s)

Article info:

Received: 12 May 2017

Accepted: 20 Sep 2017

Available Online: 01 Feb 2018

Keywords:

Psychodrama,

Adolescent, Girls, Health

\section{A B S T RA C T}

Background: During the growth process, young adults are often exposed to and involved in a number of risky behaviors which can have permanent social and health-related consequences. Moreover in clinical practice with adolescents, they frequently miss to comply with a therapeutic program. In this regard, designing proper interventions for adolescent behaviors is necessary. Psychodrama is a kind of non-scripted theater often used as a psychotherapy. The purpose of this review is to determine the effect of psychodrama on the health of adolescent girls.

Methods: Resources were searched in the databases of Scopus, Ovid, Science Direct, PubMed, Web of Science, IranMedex, and SID, with keywords of "psychodrama", "adolescence", "teenager", "health", and "girls". Both English and Persian resources without time limitation were reviewed.

Results: In total, 1840 relevant studies were found. By respecting inclusion criteria, 8 interventional studies were selected to be included in this review. In these studies, some of the effects of psychodrama, such as improving anxiety, depression, oppositional deviant disorder, hyperactivity, frustration, emotional regulation, aggression, conflict resolution skills, forgiveness, self-esteem, and communication skills were determined.

Conclusion: The study results indicate improvement of some topics of mental or social health of the adolescent girls. It is suggested that other topics of mental and social health be investigated and more valid studies be designed on the effects of psychodrama on the mental and social and physical health of adolescent girls.

\section{Background}

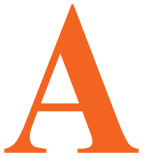

dolescence is an intermediate stage of mental and physical human development occurring between puberty and adulthood.
Important changes introduced at all levels during adolescence include biological, psychological, and maturity changes (Diamantopoulou \& Verhulst 2011). In the adolescent development, youth are often exposed to or involved in a number of risky behaviors which can have

* Corresponding Author:

Seyedeh Fatemeh Vasegh Rahimparvar, PhD

Address: Department of Midwifery and Reproductive Health, School of Nursing and Midwifery, Tehran University of Medical Sciences, Tehran, Iran. Tel: +98 (912) 2106416

E-mail: vaseghrh@tums.ac.ir 
permanent social and health-related consequences (Gullone \& Moore 2000).

Unfortunately in clinical practice with adolescents, they frequently do not comply with a therapeutic program. This compliance refers to "the level to which a patient's behavior agrees with the clinical prescription in terms of following diets, taking drugs, or performing other lifestyle changes." Given the range and importance of adolescent's noncompliance, extensive research has conducted to clarify its measurement, recognition, and determinants (Friedman \& Litt 1987). In this regard, development of specific interventions for adolescent behaviors seems necessary (Diamantopoulou \& Verhulst 2011).

In the last decade, the study of feelings and their significance in behavior have gained much interest among researchers (Llorca, Malonda \& Samper 2017). Recently, the psychological and social aspects of the clients' noncompliance have received much attention, too. Investigations of intervention methods based on established psychological values have yielded encouraging results. Lots of these techniques are applicable in clinical settings (Friedman \& Litt 1987). One of these interventional methods is psychodrama (Thabet et al. 2009).

Psychodrama is a kind of non-scripted theater often used as a method of psychotherapy. In psychodrama, the clients use unplanned performance, dramatic selfpresentation or role playing to understand their lives and gain insight into them (Pio-Abreu \& Villares-Oliveira 2007). However, conducting psychodrama requires extensive training (Thabet et al. 2009). Only, a licensed psychodramatist can direct a psychodrama therapy group. In this procedure, the real-life is reenacted and the past situations or inner mental processes are acted out in the present time. Then the individuals or groups evaluate their behaviors and deeply understand specific situations in their lives. Psychodrama is an innovative method to explore and solve personal problems.

Psychodrama is most often used in a group setting; and the group members serve as therapeutic agents for others. Thus psychodrama is an individual psychotherapy performed in a group, and it is not a kind of group therapy. It may also be utilized in a clinical or communitybased settings (Pio-Abreu \& Villares-Oliveira 2007). In general, psychodrama is a technique that helps the individuals resuscitate the events in their lives instead of just talking about their social and psychological problems (Thabet et al. 2009). Psychodrama has proven benefi- cial with adolescents and even more advantageous with adolescents than adults (Mackay, Gold \& Gold 1987).

One of the most important duties of nurses and midwives is health education to adolescent girls. In this regard, psychodrama can be conducted by them. The purpose of this review is to determine the effect of psychodrama on the health of adolescent girls.

\section{Materials and Methods}

This study is a systematic review assessed the studies conducted on the effects of psychodrama, as an intervention, on the health of the adolescence girls. The review was prepared according to PRISMA-P (the Preferred Reporting Items for Systematic review and Meta-Analysis Protocols) used as a guide for authors to present their systematic review (Shamseer et al. 2015).

\section{Eligibility criteria}

The inclusion criteria were determined according to PICOS (P: Population, I: Interventions, C: Comparisons, O: Outcomes, and S: Study design) (Centre for Reviews and Dissemination 2009). The selected articles were those that their study participants were the girls aged between 12 and 18 years and psychodrama were determined as an intervention program for improving their health. Moreover only the interventional studies such as randomized controlled trials, quasi-experimental, and before-after studies were selected. Also the resources published in English and Farsi with full text were selected as high quality studies.

\section{Search strategy and databases}

Resources were searched in the international databases including Scopus, Ovid, Science Direct, PubMed, Web of Science; and in the national databases such as IranMedex and SID; with English keywords as "psychodrama", "adolescence", "teenager", "health and girls", and equivalent Farsi keywords. Databases were explored on March 27, 2018, without time limitation.

After searching in the databases, the titles and abstracts of the studies were analyzed based on PICOS criteria, then the selected resources were assessed for methodological validity. All of the processes were performed by two authors. For this purpose, a checklist including the information of this study, including study title, first author (y), study type, sample size, intervention and outcomes was developed. 


\section{Results}

A total of 1840 studies (Scopus 430, Ovid 210, Science Direct 125, PubMed 12, Web of Science 17; IranMedex 49 , and SID 98) were found. Finally 8 studies were selected to be included in this review. The flowchart of this process is presented in PRISMA flow diagram (Figure 1).

Table 1 presents the characteristics of these 8 studies conducted on the effect of psychodrama on the health of adolescent girls. The selected studies were published from 2009 to 2016. Five of these studies were quasiexperimental with pre-test, post-test design and control group; two studies were randomized controlled trial and one was a before-after study without control group. The sample size of these studies were between 18 and 84 individuals. In five studies, all of the participants were girls and in three, both boys and girls were included. The psychodrama as the intervention lasted 10-14 sessions, each session for 1.5-2 h, one or two session per week. Also in each study, the process of psychodrama had been explained with specific program.

Also the outcomes of psychodrama interventions in these 8 studies included reducing anxiety, depression, physical complaints, hyperactivity, aggression, oppositional deviant disorder, and frustration with obstacle dominance or survival need. It also included increasing emotional regulation, conflict resolution skills, conduct disorder, forgiveness, family and social and physical self-esteem and relation skills. However, it did not cause any significant changes in self-defense, emotional transparency, physical and verbal aggression (As the subscales of aggression) and educational self-esteem (As a subscale of self-esteem).

In general, the final selected studies had significant shortcomings in terms of research methodology such

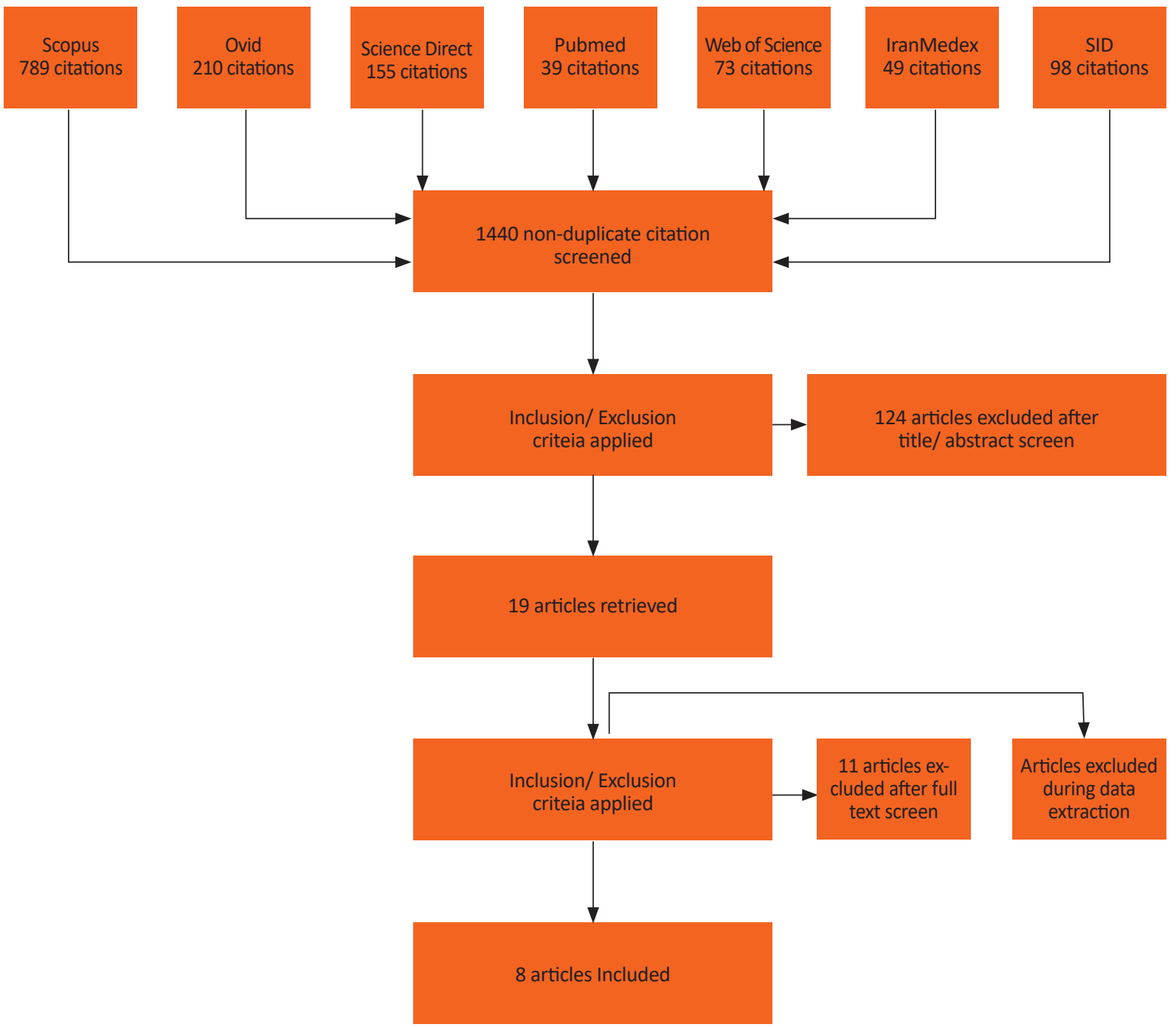

Figure 1. PRISMA flow diagram for search process

Client- Centered Nursing Care 
Table 1. Characteristics of the studies conducted on the effect of psychodrama on the health of adolescent girls

\begin{tabular}{|c|c|c|c|c|c|c|}
\hline No. & Study Title & $\begin{array}{l}\text { First Author } \\
\text { (Year) }\end{array}$ & Study Type & Sample Size & Intervention & Outcomes \\
\hline 1 & $\begin{array}{l}\text { Efficacy of psycho- } \\
\text { drama techniques } \\
\text { in internalizing } \\
\text { symptoms (anxiety, } \\
\text { depression and so- } \\
\text { matization) among } \\
\text { adolescent girls } \\
\text { victims of bullying } \\
\text { in Kermanshah City }\end{array}$ & $\begin{array}{l}\text { Jamshidi } \\
\text { Nazar et al. } \\
\text { (2014) }\end{array}$ & $\begin{array}{l}\text { Quasi-exper- } \\
\text { imental with } \\
\text { pre-test, } \\
\text { post-test } \\
\text { and control } \\
\text { group }\end{array}$ & $\begin{array}{l}\text { Thirty adolescent } \\
\text { girls who achieved } \\
\text { higher scores in the } \\
\text { bully/victim ques- } \\
\text { tionnaire, } 15 \text { girls in } \\
\text { experimental and } 15 \\
\text { girls in control group }\end{array}$ & $\begin{array}{l}\text { Eight group psycho- } \\
\text { drama sessions ( } 1.5 \\
\text { hours- two times } \\
\text { per week) }\end{array}$ & $\begin{array}{l}\text { Reducing the internalizing } \\
\text { symptoms and its sub- } \\
\text { scales including anxiety- } \\
\text { depression, isolation- } \\
\text { depression, and physical } \\
\text { complaints }\end{array}$ \\
\hline 2 & $\begin{array}{l}\text { Effectiveness of } \\
\text { school based } \\
\text { psychodrama in } \\
\text { Improving mental } \\
\text { health of Palestinian } \\
\text { adolescents }\end{array}$ & $\begin{array}{l}\text { Thabet et al. } \\
\text { (2009) }\end{array}$ & $\begin{array}{l}\text { Intervention- } \\
\text { al study with } \\
\text { pre-test, } \\
\text { post-test and } \\
\text { without con- } \\
\text { trol group }\end{array}$ & $\begin{array}{l}\text { Eighty-four school } \\
\text { adolescents ( } 56 \\
\text { boys and } 28 \text { girls) } \\
\text { aged } 12-17 \text { years } \\
\text { from three schools } \\
\text { selected randomly }\end{array}$ & $\begin{array}{l}\text { Carbonell and } \\
\text { Parteleno-Berehmi } \\
\text { Psychodrama } \\
\text { model (1999), } \\
\text { focused on giving } \\
\text { adolescent the op- } \\
\text { portunity to cope } \\
\text { with trauma }\end{array}$ & $\begin{array}{l}\text { Decreasing the mental } \\
\text { health including Opposi- } \\
\text { tional deviant disorder, } \\
\text { hyperactivity, overanxious, } \\
\text { separation anxiety and } \\
\text { depression; and increasing } \\
\text { conduct disorder }\end{array}$ \\
\hline 3 & $\begin{array}{l}\text { Studying the effec- } \\
\text { tiveness of psycho- } \\
\text { drama approach on } \\
\text { reducing frustration } \\
\text { and increasing emo- } \\
\text { tional regulation of } \\
\text { street children }\end{array}$ & $\begin{array}{l}\text { Gerama and } \\
\text { Dehghan } \\
\text { (2016) }\end{array}$ & $\begin{array}{l}\text { An inter- } \\
\text { ventional } \\
\text { study with } \\
\text { randomly } \\
\text { assigned into } \\
\text { two groups } \\
\text { (control and } \\
\text { experimental) }\end{array}$ & $\begin{array}{c}\text { Twenty-two street } \\
\text { children, } 14-18 \text { years } \\
\text { old in Mehr Karaj } \\
\text { House }\end{array}$ & $\begin{array}{l}\text { Group counseling } \\
\text { with psychodrama } \\
\text { approach for } 10 \\
\text { sessions ( } 2 \text { hours } \\
\text { weekly) }\end{array}$ & $\begin{array}{l}\text { Reducing frustration in fac- } \\
\text { tors of obstacle dominance } \\
\text { and survival need, but not } \\
\text { in factor of self-defense; } \\
\text { and increasing the emo- } \\
\text { tional regulation in terms } \\
\text { of reception, objectives, } \\
\text { momentum, knowledge } \\
\text { and strategies, but not in } \\
\text { terms of emotional trans- } \\
\text { parency }\end{array}$ \\
\hline 4 & $\begin{array}{l}\text { A comparative } \\
\text { investigation of the } \\
\text { effects of cognitive- } \\
\text { behavioral group } \\
\text { practices and } \\
\text { psychodrama on } \\
\text { adolescent aggres- } \\
\text { sion }\end{array}$ & $\begin{array}{l}\text { Karatas and } \\
\text { Gokcakana } \\
\text { (2009) }\end{array}$ & $\begin{array}{l}\text { A quasi-ex- } \\
\text { perimental, } \\
\text { with two } \\
\text { experiments } \\
\text { (cognitive- } \\
\text { behavioral } \\
\text { and psy- } \\
\text { chodrama) } \\
\text { groups and } \\
\text { one control } \\
\text { group }\end{array}$ & $\begin{array}{l}\text { Thirty-six adolescent } \\
\text { students who had } \\
\text { the highest aggres- } \\
\text { sion levels according } \\
\text { to The Aggression } \\
\text { Scale (Buss \& War- } \\
\text { ren, 2000) were ran- } \\
\text { domly divided into } \\
\text { three equal groups, } \\
\text { in each group } 12 \\
\text { adolescents, } 6 \text { girls } \\
\text { and } 6 \text { boys }\end{array}$ & $\begin{array}{l}\text { Group-based } \\
\text { psychodrama tech- } \\
\text { niques were applied } \\
\text { in } 14 \text { sessions }\end{array}$ & $\begin{array}{l}\text { A positive effect on total } \\
\text { aggression score: anger, } \\
\text { hostility, and indirect ag- } \\
\text { gression scores, but had } \\
\text { no effect on physical and } \\
\text { verbal aggression scores }\end{array}$ \\
\hline
\end{tabular}

Investigating the effects of group practice performed 5 using psychodrama techniques on adolescents' conflict resolution skills

Karatas

(2011) a quasi-experimental research with control group
Twenty-four high school adolescent students and in each group 12 students, 6 boys and 6 girls
Psychodrama was performed once a week for 10 weeks, each session lasted for 90-120 minutes

Favorable effects on adolescents' conflict resolution skills. The follow-up scores in 12-week after intervention was compared with immediately after intervention did not find difference in conflict resolution skills and sub-dimension; so it seems that the effect

lasts for a long time.

Twenty-four ado-

The effect of psychodrama on

6 steem and forgiveness of female adolescents with divorced parents

\section{Gorji et al. perimental}

(2011)
A pre-test, post-test with ex-

lescent girls, aged

14-17 years, with divorced parents and lived with and control their mother, were groups and follow-up design divided into experimental and control group (12 girls in each group)
Ten two-hour sessions of psychodrama, twice a week with programed designs for each session according to the protagonist, as the main character in each session drama
The significant effect on forgiveness and selfesteem (family, social, physical self-esteem but it had no impact on the educational self-esteem) 


\begin{tabular}{|c|c|c|c|c|c|c|}
\hline No. & Study Title & $\begin{array}{l}\text { First Author } \\
\text { (Year) }\end{array}$ & Study Type & Sample Size & Intervention & Outcomes \\
\hline 7 & $\begin{array}{l}\text { The effect of } \\
\text { psychodrama on de- } \\
\text { creasing high-school } \\
\text { girls' aggression in } \\
\text { Kashan }\end{array}$ & $\begin{array}{l}\text { Zandipoor } \\
\text { (2010) }\end{array}$ & $\begin{array}{l}\text { An Inter- } \\
\text { vention } \\
\text { study with } \\
\text { pre-test, } \\
\text { post-test } \\
\text { and control } \\
\text { group }\end{array}$ & $\begin{array}{l}\text { One hundred high- } \\
\text { school girls selected } \\
\text { with randomized } \\
\text { sampling method; } \\
\text { then according to } \\
\text { Buss Aggression } \\
\text { Scale, } 18 \text { girls with } \\
\text { highest aggression } \\
\text { levels were selected } \\
\text { and randomly divid- } \\
\text { ed into two groups, } \\
9 \text { girls in each group }\end{array}$ & $\begin{array}{l}\text { The psychodrama } \\
\text { techniques were } \\
\text { applied in } 10 \text { ses- } \\
\text { sions according to } \\
9 \text { Principles and } 14 \\
\text { phenomenon of } \\
\text { psychodrama }\end{array}$ & $\begin{array}{c}\text { Significant decrease in } \\
\text { total aggression and the } \\
\text { subscales: Physical aggres- } \\
\text { sion, oral aggression, anger } \\
\text { and hostility }\end{array}$ \\
\hline 8 & $\begin{array}{l}\text { The effect of psy- } \\
\text { chodrama educa- } \\
\text { tion on relationship } \\
\text { skills and aggression } \\
\text { of aggressive girls }\end{array}$ & $\begin{array}{l}\text { Khoubani, } \\
\text { Zadehmo- } \\
\text { hammadi \& } \\
\text { Jarareh } \\
\text { (2014) }\end{array}$ & $\begin{array}{l}\text { A quasi- } \\
\text { experimen- } \\
\text { tal with } \\
\text { pre-test, } \\
\text { post-test } \\
\text { and control } \\
\text { group }\end{array}$ & $\begin{array}{l}\text { In 1950, girls from } \\
\text { Mead stage school } \\
\text { (11-15 years), } 30 \\
\text { girls were selected } \\
\text { based on high } \\
\text { scores in aggression } \\
\text { questionnaire, then } \\
\text { divided into two } \\
\text { groups as interven- } \\
\text { tional and control } \\
\text { group }\end{array}$ & $\begin{array}{l}\text { Twelve sessions of } \\
\text { psychodrama with } \\
3 \text { stage (warm- } \\
\text { up, enactment } \\
\text { and sharing) and } \\
\text { some techniques } \\
\text { (protagonist, ego } \\
\text { helpers, double } \\
\text { technique, reversal, } \\
\text { mirror technique, } \\
\text { soliloquy and } \\
\text { future projection } \\
\text { technique) }\end{array}$ & $\begin{array}{l}\text { Significantly increasing of } \\
\text { relation skills and decreas- } \\
\text { ing of aggression }\end{array}$ \\
\hline
\end{tabular}

as study design, sampling method, randomization, and sample size. For example, the sampling method of five studies were not based on randomization (Jamshidi Nazar et al. 2014; Karatas 2011; Gorji et al. 2011; Khoubani, Zadehmohammadi \& Jarareh 2014) and one study did not have a control group (Thabet et al. 2009). Also the sample size in most studies was small. Except Thabet et al. (2009) study which lacked a control group and the sample size was 84 ; in the rest of the studies with control group, the sample size in the intervention group was 9-15, and the mean sample size in intervention groups was approximately 12 . However, due to the small number of interventional studies in this subject and no access to the full text of older resources, we tried to select studies with the least research pitfalls.

\section{Discussion}

To determine the effect of psychodrama on the health of adolescent girls in this systematic review, 8 studies were selected according to the inclusion criteria. All studies had been conducted in the recent decade. Although the older resources existed on this topic, their full texts were not available. However, the selected studies had small sample size with some pitfalls in methodology; so the studies with the fewest research errors were selected. Despite the lack of recent interventional studies on psychodrama in the world, a significant number of interventional studies about psychodrama have been conducted in Iran.

Regarding the few number of interventional studies on psychodrama in the world in recent decade compared to the past decade, Karatas (2011) believed that psychodrama was very influential in the early years of the 20th century. Then it dominated the group psychotherapy but its influence in the field of group psychotherapy diminished in the United States in consequent years. On the other hand, the psychodrama popularity soared up in South America, Europe, the Far East and elsewhere. Some suggested that the observed decline in the popularity of psychodrama in North America is due to the poor scientific validity regarding the interventional research on psychodrama (Karatas 2011).

According to our 8 selected study results, psychodrama as an intervention produced some outcomes. These outcomes comprised reducing the internalizing symptoms such as anxiety-depression, isolation-depression and physical complaints (Jamshidi Nazar et al. 2014); decreasing the oppositional deviant disorder, hyperactivity, overanxious, separation anxiety and depression; increasing conduct of adolescents in time of war and conflicts (the participants of this study were Palestinians that live with war) (Thabet et al. 2009); reducing frustration (in term of obstacle dominance and survival need); and increasing the emotional regulation (in terms of reception, 
objectives, momentum, knowledge and strategies) of street children. However, psychodrama had no effect on self-defense (as a subscale of reducing frustration) and emotional transparency (as a subscale of emotional regulation) (Geram \& Dehghan 2016).

It positively affected total aggression score and its subscales, including anger, hostility, and indirect aggression scores of aggressive adolescents, but had no effect on physical and verbal aggression (Karatas \& Gokcakana 2009). It improved the conflict resolution skills of the adolescents with low problem solving skill (Karatas, 2011), by having significant effects on forgiveness and self-esteem (family, social and physical self-esteem). But it had no impact on the educational self-esteem of adolescent girls with divorced parents who lived with their mothers (Gorji et al. 2011).

Finally, it decreased total aggression and its subscales (physical aggression, oral aggression, anger and hostility) in adolescent girls with high aggression level (Zandipoor 2010) and improved their relation skills (Khoubani, Zadehmohammadi \& Jarareh 2014). It seems that lack of psychodrama impact on some subscales in the above studies is due to the small sample size.

In general, the 8 selected study results indicate that outcomes of psychodrama were mostly about improving the mental and or social health of adolescent girls, including positive effects on anxiety, depression, oppositional deviant disorder, hyperactivity, frustration, emotional regulation, aggression, conflict resolution skills, forgiveness, self-esteem, and relation skills. However, the number of studies on the impact of psychodrama on physical health (not mental/social health) of adolescent girls is limited.

Some documents reported that psychodrama is effective on improving the physical signs of some diseases. In this regard, Bektas (2006) reported a reduction of glycosylated hemoglobin level in the diabetic children after psychodrama, though this could not be considered a direct result of psychodrama. In this study, the diabetic children might have benefited indirectly through changes in their parents' behavior and better communication within them. Also the role that psychodrama in the treatment and understanding of asthma is argued according to medical knowledge and clinical experience by some researchers (Parkinson 1997). Using the psychodrama has positively affected blood pressure and heart disease as well (Schalling 1973). Of course, the effect of psychodrama on these diseases is not a direct one. In fact, the psychological or mental effects of psychodrama will improve the signs and symptoms of these diseases (Bektas 2006). However according to our search in databases, we did not find any study showing the impact of psychodrama on the signs and symptoms of adolescent girls' diseases.

As an adolescent's identity develops, he or she compares himself or herself to healthy, active peers, and adults. The limitations produced by preventive regimen or medication may make the adolescent feel defective or different. Therefore, the adolescent may reject to follow the prescriptions given during this period. Then, his or her physical health may be endangered (Friedman \& Litt 1987). The appealing nature of psychodrama is attributed to its powerful influence as seen in clinical practice (Karatas 2011). It is suggested that further studies be conducted on the effects of psychodrama on the physical health of adolescent girls.

Also the existing studies about the effects of psychodrama are limited to the number of mental and or social health issues. Therefore, it is suggested that some studies be conducted on other topics, such as lack of coping mechanisms (Llorca, Malonda \& Samper 2017), smoking control programs (Carolyn 2009), use of drug substances (Karatay and Gürarslan, 2017), and body dissatisfaction (Thompson et al. 1999). The study of mental health including the feelings and emotions and also their influences in the people's behavior has gained popularity among researchers in the last decades (Llorca, Malonda \& Samper 2017).

Also we recommend that valid studies be conducted on the effects of psychodrama on the mental and or social health of adolescent girls. Considering the quality of the studies, there is not enough evidence supporting the importance of psychodrama methods in mental and or social health of the adolescent girls. It is, therefore, necessary to study psychodrama more deeply in future studies with larger sample size.

According to this systematic review, psychodrama can improve some mental or social health problems of adolescent girls. These positive effects included decrease in anxiety, depression, oppositional deviant disorder, hyperactivity, aggression, frustration, forgiveness, and increase in the emotional regulation, conflict resolution skills, self-esteem, and relation skills. However, there was not any study on the impact of psychodrama on the signs and symptoms of adolescent girls' physical diseases. Therefore it is suggested that further studies be conducted on the effects of psychodrama on the physical health of adolescent girls. Also we suggest that some studies be conducted on the effects of psychodrama on 
the other topics of mental or social health such as lack of coping mechanisms in adolescent girls. Also we recommend that more valid studies be designed about the effects of psychodrama on the mental, social, or physical health of adolescent girls.

There were some limitations in this systematic review. Only the studies published in English or Persian language were included in the review. In addition the full text of some articles were not available. Also some older related resources exist that we did not manage to access them.

\section{Ethical Considerations}

\section{Compliance with ethical guidelines}

This paper was approved by Ethics Committee of Iran University of Medical Sciences (IR.IUMS.REC 1396.32694).

\section{Funding}

This paper is based on an approved research registered with No. 96-04-123-32694 in Nursing Care Research Center, Iran University of Medical Sciences, Tehran.

\section{Conflict of interest}

The authors declared no conflict of interest.

\section{References}

Bektas, B., 2006. Psychodrama: Helping families to adapt to childhood diabetes. European Diabetes Nursing Banner, 3(3), pp. 149-53. [DOI:10.1002/edn.64]

Blythe, A., et al., 2017. Changes in anxiety following a randomized control trial of a theatre-based intervention for youth with autism spectrum disorder. Autism, 21(3), pp. 333-43. [DOI:10.1177/1362361316643623] [PMID] [PMCID]

Carolyn, C. et al., 2009. A school-based environmental intervention to reduce smoking among high school students: The Acadiana Coalition of Teens against Tobacco (ACTT). International Journal of Environmental Research and Public Health, 6(4), pp. 1298-316. [DOI:10.3390/ijerph6041298] [PMID] [PMCID]

Centre for Reviews and Dissemination, 2009. Systematic reviews: $C R D$ 's guidance for undertaking reviews in healthcare. York: University of York NHS Centre for Reviews \& Dissemination.

Diamantopoulou, S. \& Verhulst, F. C., 2011. Gender differences in the development and adult outcome of co-occurring depression and delinquency in adolescence. American Psychological Association, 120(3), pp. 644-55. [DOI:10.1037/a0023669] [PMID]
Friedman, I. \& Litt, I., 1987. Adolescents' compliance with therapeutic regimens psychological and social aspects and intervention. Journal of Adolescent Health Care, 8(1), pp. 52-67. [DOI:10.1016/0197-0070(87)90246-4] [PMID]

Fuhriman, A. \& Burlingame, G. M., 1994. Group psychotherapy: An empirical and clinical synthesis. New York: Wiley. [PMID]

Gerama, K., \& Dehghan, A., 2016. Studying of the effectiveness of psychodrama approach on reducing frustration and increasing emotional regulation of street children. International Academic Journal of Humanities, 3(1), pp. 6-15.

Gorji, Z., et al., 2011. [The effect of psychodrama on self-esteem and forgiveness of female adolescents with divorced parents (Persian)]. Journal of Family Research, 7(7.1), pp. 195-209.

Gullone, E. \& Moore, S., 2000. Adolescent risk-taking and the fivefactor model of personality. Journal of Adolescence, 23(4), pp. 293307. [DOI:10.1006/jado.2000.0327] [PMID]

Jamshidi Nazar, F., et al., 2014. [Efficacy of psychodrama techniques in internalizing symptoms (anxiety, depression and somatization) among adolescent girls victims of bullying in Kermanshah (Persian)]. Journal of Mazandaran University of Medical Sciences, 24(115), pp. 141-7.

Karatas, Z. \& Gokcakana, Z., 2009. Comparative investigation of the effects of cognitive-behavioral group practices and psychodrama on adolescent aggression. Educational Sciences: Theory \& Practice, 9(3), pp. 1441-52.

Karatas, Z., 2011. Investigating the effects of group practice performed using psychodrama techniques on adolescents' conflict resolution skills. Educational Sciences: Theory \& Practice, 11(2), pp. 609-614.

Karatay, G. \& Gürarslan, B., 2017. Effects of role-playing scenarios on the self-efficacy of students in resisting sgainst substance addiction: A pilot study. The Journal of Health Care Organization, Provision, and Financing, 54, p. 46958017720624 [DOI:10.1177/0046958017720624]

Khoubani, M., Zadehmohammadi, A. \& Jarareh, J., 2014. [Effectiveness of psychodrama training on communication skills and aggression of aggressive girls (Persian)]. Journal of Applied Psychology, 7(4), pp. 27-44.

Llorca, A., Malonda, E. \& Samper, P., 2017. Anxiety in adolescence. Can we prevent it? Medicina Oral Patologia Oraly Cirugia Bucal, 22(1), pp. e70-5. [DOI:10.4317/medoral.21754]

Mackay, B., Gold, M. \& Gold, E., 1987. Pilot study in drama therapy with adolescent girls who have been sexually abused. The Arts in Psychotherapy, 14(1), pp. 77-84. [DOI:10.1016/01974556(87)90037-2]

Parkinson, P., 1997. The Contribution of psychodrama to the understanding and treatment of asthma. Australian and Aotearoa New Zealand Psychodrama Association (ANZPA) Journal, 6, pp. 1-43.

Pio-Abreu, J. L., Villares-Oliveira, C., 2007. How does psychodrama work? In B. Clark, J. Burmeister, \& M. Maciel (eds.), Psychodrama: Advances in Theory and Practice. Abingdon: Taylor and Frances. [PMID]

Schalling, D., 1973. Personality correlates of elevated blood pressure. Stress and anxiety. Philadelphia: Hemisphere publishing corporation. 
Shamseer, L. et al., 2015. Preferred reporting items for systematic review and meta-analysis protocols (PRISMA-P) 2015: elaboration and explanation. BMJ, 349, pp. g7647. [DOI:10.1136/bmj.g7647]

Thabet, A. A., et al., 2009. Effectiveness of school based psychodrama in improving mental health of Palestinian Adolescents. Arabpsynet E. Journal, 24, pp. 67-71.

Thompson, J. K., et al., 1999. Exacting beauty: Theory, assessment, and treatment of body image disturbance. Washington, D.C.: American Psychological Association. [DOI:10.1037/10312-000]

Zandipoor, T., 2010. [The effect of psychodrama on decreasing highschool girls aggression in Kashan (Persian)] [MSc. Thesis]. Tehran: Alzahra University. 